\title{
Virulence-associated factors in Escherichia coli strains isolated from children with urinary tract infections
}

\author{
L. SIEGFRIED* $\dagger$, MARTA KMEŤOVÁ†, HANA PUZOVÁ†, MÀRIA MOLOKÁČOVÁ $\ddagger$ and J. FILKA§ \\ $\dagger$ Institute of Medical Microbiology, Faculty of Medicine, Safárik University, Košice, $\ddagger$ Departments of Clinical \\ Microbiology and §Pediatrics, University Hospital, Košice, Slovakia
}

\begin{abstract}
Summary. One hundred and sixty-eight strains of Escherichia coli were isolated from cases of pyelonephritis (24) and lower urinary tract infections (UTI) (144) from hospitalised and outpatient children up to 2 years old. These strains were investigated for the expression of $P$ fimbriae (PF), mannose-resistant and mannose-sensitive haemagglutination, cell-surface hydrophobicity, serum resistance and the production of $\alpha$-haemolysin (AH), colicins and aerobactin. $\mathrm{PF}, \mathrm{AH}$, aerobactin production and serum resistance were significantly more frequent amongst strains expressing mannose-resistant haemagglutination. $\mathrm{PF}$ and $\mathrm{AH}$ production was significantly more frequent in pyelonephritogenic strains than in lower UTI strains. Serotypes $\mathrm{O} 6$ and $\mathrm{O} 112$ were isolated most frequently and plasmids were found in the majority of strains tested.
\end{abstract}

\section{Introduction}

Escherichia coli is one of the most frequent causes of extra-intestinal diseases including urinary tract infections (UTI). In uropathogenic E. coli strains, virulence factors include the ability to adhere to uro-epithelial cells, ${ }^{1-3}$ some $\mathrm{O}$ and $\mathrm{K}$ antigens, ${ }^{4.5}$ and resistance to phagocytosis and to the bactericidal action of normal serum. ${ }^{6.7}$ Other factors known to contribute to the virulence of $E$. coli include the production of $\alpha$ haemolysin $(\mathrm{AH}),{ }^{8,9}$ colicins, ${ }^{10,11}$ aerobactin, ${ }^{12,13}$ cytotoxic necrotising factor ${ }^{14,15}$ and cell-surface hydrophobicity. ${ }^{16}$ Adherence to uro-epithelial cells is mediated by fimbrial and non-fimbrial adhesins. Among the former, $\mathrm{P}, \mathrm{S}, \mathrm{M}$ and $\mathrm{X}$ fimbriae have been described ${ }^{17-19}$ and these may cause mannose-resistant haemagglutination (MRHA) of human erythrocytes.

In this study, the incidence of virulence factors was investigated in $168 \mathrm{E}$. coli strains isolated from the urine of children with pyelonephritis or lower UTI.

\section{Materials and methods}

\section{Bacterial strains}

One hundred and sixty-eight strains of $E$. coli were isolated from the urine of patients with either pyelonephritis (24) or lower UTI (144). Most were isolated from hospitalised infants $<2$ years old. From each primary isolation plate of MacConkey agar, only one colony was picked for further investigation. Identifi-

Received 20 July 1993; revised version accepted 16 Feb. 1994.

* Correspondence should be sent to Dr L. Siegfried, Matuškova 6 , 04011 Košice, Slovakia. cation of $E$. coli was based on biochemical properties. $O$ serotyping by slide agglutination was done first with eight polyvalent $(\mathrm{OA}, \mathrm{OB}, \mathrm{OC}, \mathrm{OD}, \mathrm{OE}, \mathrm{OF}, \mathrm{OG}, \mathrm{OH})$ and then with 52 monovalent antisera (OA-O26, O55, O111, O127; OB-O86, O119, O124, O125, O126, O128; OC-O1, O2, O3, O4, O5, O6, O 7; OD-O8, O9, O10, O11, O12, O13, O14; OE-O15, O16, O17, O18, $\mathrm{O} 19, \mathrm{O} 20, \mathrm{O} 21$; OF-O22, O23, O24, O27, O28, O29, O30; OG-Ca18, O32, O50, O75, O143, O144, Ca792; $\mathrm{OH}-\mathrm{O} 25, \mathrm{O} 78, \mathrm{O} 85, \mathrm{O} 112, \mathrm{O} 139, \mathrm{O} 141, \mathrm{O} 142$ ) (Imuna, Slovakia).

The diagnosis of acute pyelonephritis and lower UTI (acute cystitis and urethritis) was based on laboratory and clinical investigations. The former was defined by the presence of fever $\left(>38 \cdot 5^{\circ} \mathrm{C}\right)$, frequency of urination, positive urine culture $\left(\geqslant 10^{5} \mathrm{cfu} / \mathrm{ml}\right.$ of urine), pyuria ( $>10$ white blood cells/high power field), elevated erythrocyte sedimentation rate $(>20 \mathrm{~mm} / \mathrm{h})$, an increased concentration of Creactive protein $(\geqslant 20 \mathrm{mg} / \mathrm{L})$ and reduced concentrating capacity $(<600 \mathrm{mOsm} / \mathrm{L})$. Cystitis or urethritis was indicated by a history of frequency of urination, dysuria, suprapubic pain, significant bacteriuria ( $>10^{5} \mathrm{cfu} / \mathrm{ml}$ of urine) but without fever, and with normal renal function.

\section{Haemagglutination test}

Bacteria were inoculated into $5 \mathrm{ml}$ of MuellerHinton Broth (Difco) and incubated statically at $37^{\circ} \mathrm{C}$ for 5 days until a pellicle was formed. From the pellicle, bacteria were inoculated on to CFA agar ${ }^{20}$ containing Casamino acids $1 \% \mathrm{w} / \mathrm{v}$, yeast extract $0.15 \% \mathrm{w} / \mathrm{v}$, $\mathrm{MgSO}_{4} 0.005 \% \mathrm{w} / \mathrm{v}, \mathrm{MgCl}_{2} 0.0005 \% \mathrm{w} / \mathrm{v}$ and agar $2 \% \mathrm{w} / \mathrm{v}$ and cultivated at $37^{\circ} \mathrm{C}$ for $18 \mathrm{~h}$. Haem- 
agglutination was performed in round-bottomed microtitration plates. ${ }^{15}$ One drop $(100 \mu \mathrm{l})$ of bacterial suspension was mixed with one drop of erythrocytes (human type A or guinea-pig; $3 \% \mathrm{v} / \mathrm{v}$ in phosphatebuffered saline, PBS) and one drop of PBS, with or without D-mannose $3 \% \mathrm{w} / \mathrm{v}$. The plate was left to rotate $(15 \mathrm{rpm})$ for $5 \mathrm{~min}$ at laboratory temperature followed by rotation for $5 \mathrm{~min}$ at $4^{\circ} \mathrm{C}$. Haemagglutination was considered to be mannose-resistant (MRHA) when it occurred in the presence and absence of mannose, and mannose-sensitive (MSHA) when it was inhibited by mannose.

\section{P fimbriae $(P F)$}

$\mathrm{PF}$ were detected by a particle agglutination test (PF test, Orion Diagnostica, Espoo, Finland) which was specific for the $\mathrm{P}$ adhesin. Briefly, one drop of bacterial suspension was mixed on a plastic slide with one drop of the test solution containing latex particles coated with the $\alpha$-D-Gal-(1-4)- $\beta$-D-Gal P receptor. Latex particles without $\mathrm{P}$ receptor served as a control. If PF were expressed by the organism, macroscopic agglutination was apparent, usually within 1 min. $^{3}$

\section{Cell-surface hydrophobicity}

Cell-surface hydrophobicity was measured by the salt aggregation test (SAT) with suspensions $(5 \times$ $10^{9} \mathrm{cfu} / \mathrm{ml}$ ) in $0.2 \mathrm{M}$ phosphate buffer, $\mathrm{pH} 6.8$, of bacteria grown on CFA medium. ${ }^{15}$ Suspensions were mixed with ammonium sulphate (Lachema, Czech Republic) solutions at final molar concentrations of $2 \cdot 0,1.4,1 \cdot 0,0.4,0.1,0.06$ and 0.02 . Strains were considered to be hydrophobic when they aggregated in ammonium sulphate at concentrations $\leqslant 1.4 \mathrm{M}$.

\section{$\alpha$-Haemolysin production}

The method used for determination of $\alpha$-haemolysin production was a slight modification of those of Smith $^{21}$ and Asnani et al..$^{22}$ Cultures were incubated for $4-6 \mathrm{~h}$ at $37^{\circ} \mathrm{C}$ in alkaline meat extract broth then centrifuged $\left(12000 \mathrm{rpm}, 0^{\circ} \mathrm{C}, 20 \mathrm{~min}\right)$ and the supernate was collected. An equal amount of sheep red blood cells $(1 \%, v / v)$, washed three times in normal saline, and broth supernate were incubated at $37^{\circ} \mathrm{C}$ for $2 \mathrm{~h}$ with intermittent agitation. The suspensions were then centrifuged and the supernates were examined for signs of haemolysis.

\section{Colicin production}

Production of colicin was estimated by the method of Šmarda. ${ }^{23}$ In this method, bacterial strains were stabbed into nutrient-agar plates which were then incubated for $18 \mathrm{~h}$ at $37^{\circ} \mathrm{C}$. The agar surface was inverted over a beaker containing about $500 \mathrm{ml}$ of chloroform for $15 \mathrm{~min}$ and was then overlaid with $4 \mathrm{ml}$ of soft agar containing a suspension of $E$. coli strain ROW which is sensitive to all colicins. A zone of inhibition of growth in the overlay surrounding the stab indicated production of a colicin.

\section{Aerobactin production}

A slight modification of the chemical method of $\mathrm{Csaky}^{24}$ was used to detect aerobactin production. Briefly, E. coli culture supernates $(0.5 \mathrm{ml})$ were mixed with $0.56 \mathrm{M} \mathrm{H}_{2} \mathrm{SO}_{4}$ and autoclaved for $30 \mathrm{~min}$ to generate free hydroxylamine. After neutralisation with $1.5 \mathrm{ml}$ sodium acetate $35 \% \mathrm{w} / \mathrm{v}, 0.5 \mathrm{ml}$ of sulphanilic acid $1 \% \mathrm{w} / \mathrm{v}$ and $0.5 \mathrm{ml}$ of iodine $1.35 \% \mathrm{w} / \mathrm{v}$, both in acetic acid $30 \% \mathrm{v} / \mathrm{v}$, were added and left to stand for $5 \mathrm{~min}$ to allow oxidation of the free hydroxylamine nitrogen to nitrite. Nitrite was then estimated colorimetrically (absorbance at $526 \mathrm{~nm}$ ) after addition of $0.5 \mathrm{ml}$ of 1 -naphthylamine $0.3 \% \mathrm{w} / \mathrm{v}$ in acetic acid $30 \% \mathrm{v} / \mathrm{v}$, and incubation at room temperature for c. $30 \mathrm{~min}$. The concentration of hydroxylamine nitrogen was estimated from a standard curve constructed with known amounts of hydroxylamine hydrochloride.

\section{Plasmid extraction}

Plasmids were extracted by the alkaline lysis method $^{25}$ and lysates were subjected to agarose $0.7 \%$ w/v gel electrophoresis with TAE buffer ( $40 \mathrm{~mm}$ Tris, 5 mM sodium acetate, 1 mM EDTA, pH 7.6). Gels were stained in TAE buffer containing ethidium bromide $0.5 \mu \mathrm{g} / \mathrm{ml}$ for $40 \mathrm{~min}$ and destained in distilled water for $10 \mathrm{~min}$ before visualisation of plasmid DNA under UV illumination.

\section{Serum bactericidal assay}

The assay was done as described previously. ${ }^{26}$ Briefly, overnight cultures of E. coli, grown at $37^{\circ} \mathrm{C}$ on blood agar, were harvested and the cells were suspended in Hanks's Balanced Salts Solution (HBSS) to $2.5 \times 10^{4} \mathrm{cfu} / \mathrm{ml}$. The wells of microtitration plates were used for incubation of bacterial suspensions $(0.05 \mathrm{ml})$ with serum $(0.05 \mathrm{ml})$. Control wells contained $0.05 \mathrm{ml}$ of HBSS instead of serum. The plates were placed on a roller (angle $45^{\circ}$ ) and rotated for $180 \mathrm{~min}$. Samples $(10 \mu \mathrm{l})$ were withdrawn after incubation for $180 \mathrm{~min}$ at $37^{\circ} \mathrm{C}$ and spread on blood-agar plates. The plates were incubated for $18 \mathrm{~h}$ at $37^{\circ} \mathrm{C}$ and the viable count was determined. Susceptibility of bacteria to serum bactericidal activity was expressed as the percentage of bacteria surviving after $180 \mathrm{~min}$ in relation to the original count of bacteria determined at $0 \mathrm{~min}$ in the controls. According to the method of Benge, ${ }^{27}$ strains were termed serum sensitive if the viable count dropped to $1 \%$ of the initial value and resistant if $>90 \%$ of organisms survived after $180 \mathrm{~min}$. Strains that gave results between these values were considered to show intermediate sensitivity.

\section{Statistical analyses}

The $\chi^{2}$ test was used for statistical comparison of groups; values $<0.05$ were regarded as significant. 


\section{Results}

Of the $168 E$. coli strains investigated, 129 were typable with 52 monovalent $\mathrm{O}$ antisera. Serogroups O6 (21 strains) and O112 (17 strains) were detected most frequently. Fifty one $(35.4 \%)$ of 144 strains from lower urinary tract infections and six $(25 \%)$ of 24

Table I. Incidence of serotypes in E. coli strains from pyelonephritis and lower UTI

\begin{tabular}{|c|c|c|}
\hline \multirow{2}{*}{ Serotype } & \multicolumn{2}{|c|}{ Number of strains from } \\
\hline & Lower UTI & Pyelonephritis \\
\hline O1 & 2 & 0 \\
\hline $\mathrm{O} 2$ & 12 & 0 \\
\hline $\mathrm{O} 3$ & 2 & 0 \\
\hline $\mathrm{O} 4$ & 4 & 2 \\
\hline O5 & 1 & 0 \\
\hline O6 & 21 & 0 \\
\hline O7 & 3 & 1 \\
\hline O8 & 2 & 1 \\
\hline O9 & 2 & 0 \\
\hline O11 & 2 & 1 \\
\hline $\mathrm{O} 12$ & 9 & 3 \\
\hline $\mathrm{O} 13$ & 1 & 0 \\
\hline $\mathrm{O} 14$ & 3 & 0 \\
\hline 015 & 1 & 0 \\
\hline 016 & 1 & 1 \\
\hline $\mathrm{O} 21$ & 5 & 1 \\
\hline $\mathrm{O} 23$ & 1 & 0 \\
\hline $\mathrm{O} 25$ & 1 & 0 \\
\hline $\mathrm{O} 26$ & 1 & 0 \\
\hline $\mathrm{O} 29$ & 1 & 0 \\
\hline $\mathrm{O} 32$ & 1 & 0 \\
\hline O55 & 2 & 0 \\
\hline O75 & 5 & 1 \\
\hline O86 & 1 & 0 \\
\hline $\mathrm{O} 112$ & 14 & 3 \\
\hline 0127 & 4 & 0 \\
\hline 0141 & 2 & 1 \\
\hline $\mathrm{O} 144$ & 1 & 0 \\
\hline Ca 18 & 5 & 1 \\
\hline Ca792 & 1 & 0 \\
\hline $\mathrm{SA}^{*}$ & 4 & 1 \\
\hline NT $\dagger$ & 29 & 5 \\
\hline
\end{tabular}

* Spontaneously agglutinating in saline.

$\dagger$ Non-typable with antisera to $52 \mathrm{O}$ groups. strains from pyelonephritogenic infections belonged to the "uropathogenic" serotypes $\mathrm{O} 1, \mathrm{O} 2, \mathrm{O} 4, \mathrm{O} 6, \mathrm{O} 7$, $\mathrm{O} 8, \mathrm{O} 16, \mathrm{O} 18,025$ and $\mathrm{O} 75$. Thirty-nine isolates were not typable, including five strains which showed autoagglutination (table I).

Table II shows the distribution of the various virulence-associated factors, in relation to haemagglutination properties, in all of the 168 isolates. MRHA of human type A erythrocytes was found in 73 $(43 \%)$, MSHA in $23(14 \%)$, and no haemagglutination ( $\mathrm{MSHA}^{-}, \mathrm{MRHA}^{-}$) in $72(43 \%)$ of isolates. Of the 73 strains showing MRHA, expression of $\mathrm{PF}$ was found in $82 \%$, production of $\mathrm{AH}$ in $80 \%$, cell-surface hydrophobicity in $81 \%$, aerobactin production in $78 \%$, serum resistance in $68 \%$ and colicin production in $34 \%$. Of $85 \mathrm{PF}^{-}$strains, 60 $(70 \%)$ did not cause haemagglutination compared to $12(16.7 \%)$ non-haemagglutinating strains among 84 $\mathrm{PF}^{+}$E. coli $(\mathrm{p}<0.01)$. In MSHA strains, expression of PF was found in only $48 \%$ ( $p<0.01$, in comparison with the MRHA group), production of $\mathrm{AH}$ in $60 \%(\mathrm{p}<0.05)$, cell-surface hydrophobicity in $83 \%$ (not significant-NS; $p>0.05$ ), production of aerobactin in $52 \%(\mathrm{p}<0.05)$, colicins in $39 \%$ (NS) and serum resistance in $48 \%(\mathrm{p}<0.01)$. Furthermore, in $\mathrm{MSHA}^{-}$, $\mathrm{MRHA}^{-}$strains, PF were detected in $17 \%(\mathrm{p}<0.01$, in comparison with the MRHA group), production of $\mathrm{AH}$ in $57 \%(\mathrm{p}<0.01)$, cellsurface hydrophobicity in $71 \%$ (NS), serum resistance in $71 \%$ (NS), production of aerobactin in $63 \%(\mathrm{p}<$ 0.05 ) and colicins in $24 \%$ (NS).

Tables III and IV show the distribution of virulenceassociated factors in relation to the type of UTI from which the strains were isolated. Of 24 strains isolated from cases of pyelonephritis (table III), 54\% were MRHA, $13 \%$ were MSHA and $33 \%$ MSHA $^{-}$, MRHA $^{-}$. Of 144 lower UTI isolates, $42 \%$ were MRHA, $14 \%$ MSHA and $44 \%$ were MSHA , $\mathrm{MRHA}^{-}$(table IV). Additionally, several isolates of each group showed MSHA of guinea-pig erythrocytes.

Among the pyelonephritogenic strains (table III), expression of $\mathrm{PF}$ was found in $71 \%, \mathrm{AH}$ in $92 \%$,

Table II. Virulence-associated factors in $168 \mathrm{E}$. coli strains in relation to haemagglutination of human type A erythrocytes

\begin{tabular}{lccc}
\hline \multirow{2}{*}{$\begin{array}{c}\text { Virulence } \\
\text { factor }\end{array}$} & \multicolumn{3}{c}{$\begin{array}{c}\text { Number (\%) of strains showing } \\
\text { haemagglutination }\end{array}$} \\
\cline { 2 - 4 } & MRHA (73) & MSHA (23) & MRHA $^{-}$, MSHA $^{-}(72)$ \\
\hline PF & $60(82 \cdot 2)$ & $11(47 \cdot 8)^{* *}$ & $12(16 \cdot 7)^{* *}$ \\
Hydrophobicity & $59(80 \cdot 8)$ & $19(82 \cdot 6)$ & $51(70 \cdot 8)$ \\
$\begin{array}{l}\alpha \text {-Haemolysin } \\
\text { Colicins } \\
\text { Aerobactin production }\end{array}$ & $60(80 \cdot 2)$ & $14(60 \cdot 0)^{*}$ & $41(57 \cdot 0)^{* *}$ \\
Serum resistance & $25(34 \cdot 2)$ & $9(39 \cdot 1)$ & $17(24 \cdot 0)$ \\
& $57(78 \cdot 1)$ & $12(52 \cdot 2)^{*}$ & $45(62 \cdot 5)^{*}$ \\
\hline
\end{tabular}

MRHA, strains causing mannose-resistant haemagglutination; MSHA, strains causing mannose-sensitive haemagglutination; $\mathrm{MRHA}^{-}, \mathrm{MSHA}^{-}$, strains not causing haemagglutination.

* Significant, $\mathrm{p}<0.05$; ** highly significant, $\mathrm{p}<0.01 ; \chi^{2}$ test used for comparison with MRHA isolates. 
Table III. Virulence-associated factors in 24 E. coli from pyelonephritis

\begin{tabular}{|c|c|c|c|c|c|c|c|c|c|}
\hline \multirow{3}{*}{$\begin{array}{c}\text { Haemagglutination } \\
\text { of human } \\
\text { erythrocyte }\end{array}$} & \multirow{3}{*}{$\begin{array}{c}\text { Number } \\
(\%) \\
\text { of strains }\end{array}$} & \multicolumn{8}{|c|}{ Number $(\%)$ of strains expressing } \\
\hline & & \multicolumn{2}{|c|}{$\begin{array}{c}\text { haemagglutination } \\
\text { of guinea-pig } \\
\text { erythrocytes }\end{array}$} & \multirow[t]{2}{*}{ PF } & \multirow[t]{2}{*}{ hydrophobicity } & \multirow[t]{2}{*}{$\mathrm{AH}$} & \multirow[t]{2}{*}{ colicin } & \multirow[t]{2}{*}{ aerobactin } & \multirow[t]{2}{*}{ serum resistance } \\
\hline & & MSHA & MRHA & & & & & & \\
\hline MRHA & $13(54)$ & 6 & 0 & 13 & 12 & 12 & 3 & 9 & 6 \\
\hline MSHA & $3(13)$ & 1 & 0 & 2 & 3 & 3 & 1 & 2 & 1 \\
\hline $\mathrm{MRHA}^{-}, \mathrm{MSHA}^{-}$ & $8(33)$ & 4 & 0 & 2 & 7 & 7 & 1 & 7 & 7 \\
\hline Total & 24 & $11(46)$ & 0 & $17(71)$ & $22(92)$ & $22(92)$ & $521)$ & $18(75)$ & $14(58)$ \\
\hline
\end{tabular}

See footnote to table II.

Table IV. Virulence-associated factors in 144 E. coli strains from lower UTI

\begin{tabular}{|c|c|c|c|c|c|c|c|c|c|}
\hline \multirow{3}{*}{$\begin{array}{c}\text { Haemagglutination } \\
\text { of human } \\
\text { erythrocyte }\end{array}$} & \multirow{3}{*}{$\begin{array}{l}\text { Number } \\
(\%) \\
\text { of strains }\end{array}$} & \multicolumn{8}{|c|}{ Number $(\%)$ of strains expressing } \\
\hline & & \multicolumn{2}{|c|}{$\begin{array}{c}\text { haemagglutination } \\
\text { of guinea-pig } \\
\text { erythrocytes }\end{array}$} & \multirow[t]{2}{*}{ PF } & \multirow[t]{2}{*}{ hydrophobicity } & \multirow[t]{2}{*}{$\mathrm{AH}$} & \multirow[t]{2}{*}{ colicin } & \multirow[t]{2}{*}{ aerobactin } & \multirow[t]{2}{*}{ serum resistance } \\
\hline & & MSHA & MRHA & & & & & & \\
\hline MRHA & $60(42)$ & 31 & 4 & 44 & 46 & 48 & 22 & 48 & 44 \\
\hline MSHA & $20(14)$ & 16 & 0 & 9 & 16 & 11 & 8 & 10 & 10 \\
\hline $\mathrm{MRHA}^{-}, \mathrm{MSHA}^{-}$ & $64(44)$ & 38 & 7 & 13 & 45 & 34 & 16 & 38 & 44 \\
\hline Total & 144 & $85(59)$ & $11(8)$ & $66(46)$ & $107(74)$ & $93(65)$ & $46(32)$ & $96(67)$ & $98(68)$ \\
\hline
\end{tabular}

See footnote to table II.

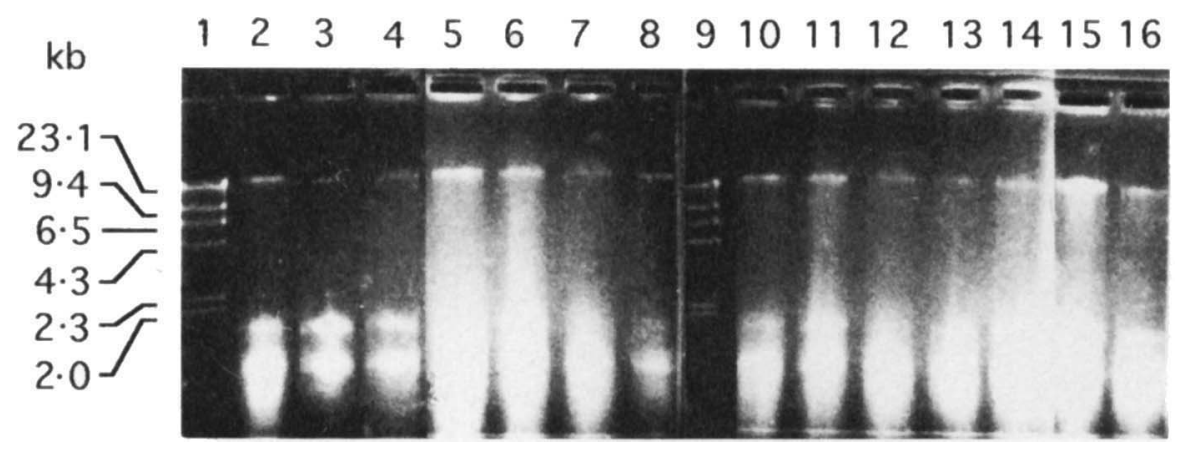

Figure. Plasmid patterns of E. coli strains from UTI. Lanes 1 and 9: HindIII digest of $\lambda$ bacteriophage used as a mol.-wt marker; 2-8, plasmid profiles of eight $E$. coli strains from lower UTI; 10-16, plasmid profiles of eight pyelonephritogenic $E$. coli strains.

colicins in $21 \%$, aerobactin production in $75 \%$, cell-surface hydrophobicity in $92 \%$ and serum resistance in $58 \%$ of the strains. When compared to these strains, $\mathrm{PF}$ and $\mathrm{AH}$ were found significantly less frequently in isolates from lower UTI (table IV), in $46 \%$ of isolates $(p<0.05)$ and in $65 \%$ of isolates ( $\mathrm{p}<0.01)$, respectively. No significant differences were found in the production of colicins ( $32 \%$ of lower UTI isolates) and aerobactin $(67 \%)$ or in the expression of cell-surface hydrophobicity $(74 \%)$ and serum resistance $(68 \%)$ when lower UTI strains were compared to the pyelonephritogenic strains.

Plasmid DNA was found in $61(69 \%)$ of 89 strains tested, including all ampicillin-resistant isolates. The majority of the strains carried one to three plasmids of $23 \cdot 1,2 \cdot 1$ and $<2 \cdot 0 \mathrm{~kb}$ (figure). There was no marked difference in plasmid DNA content between pyelonephritogenic and lower UTI isolates.

\section{Discussion}

$E$. coli strains isolated from urinary tract infections were investigated for their serotype, possession of seven virulence-associated factors and, in selected isolates, for plasmid DNA. On the basis of agglutination of human erythrocytes, isolates were divided into three groups: MRHA, MSHA and MSHA-, $\mathrm{MRHA}^{-}$. The expression of $\mathrm{PF}$ and production of $\mathrm{AH}$ and aerobactin were significantly more common in MRHA strains than in the other two compared groups. A significant difference in serum resistance 
was found only when MSHA and $\mathrm{MSHA}^{-}, \mathrm{MRHA}^{-}$ strains were compared ( $48 \%$ versus $71 \%, \mathrm{p}<0.05$ ). The highest percentage of serum-resistant strains was found among $\mathrm{MSHA}^{-}$, $\mathrm{MRHA}^{-}$strains. To our knowledge, only Jacobson $e t a l .{ }^{28}$ have looked for a correlation between PF or type I fimbriae and resistance to the bactericidal action of serum but none was found. Differences in the expression of cell-surface hydrophobicity and aerobactin production were found between the groups in the present work but these were not significant. As in the work of Hull et al., ${ }^{29}$ expression of $\mathrm{PF}$ and $\mathrm{AH}$ production were common in our collection of strains and particularly frequent in bacteria possessing MRHA. ${ }^{20,30}$

$\mathrm{PF}$ were more frequently present in pyelonphritogenic strains than in lower UTI strains. This finding is in agreement with those of others. ${ }^{31-33}$

\section{References}

1. Svanborg Eden C, Eriksson B, Hanson LA. Adhesion of Eschericha coli to human uroepithelial cells in vitro. Infect Immun 1977; 18: 767-774.

2. Ørskov I, Ørskov F. Escherichia coli in extra-intestinal infections. $J$ Hyg 1985; 95 : 551-575.

3. Kärkkäinen U, Ikäheimo R, Katila $M L$, Mäntyjärvi R. P fimbriation of Escherichia coli strains from patients with urosepsis demonstrated by a commercial agglutination test (PF test). J Clin Microbiol 1991; 29: 221-224.

4. Kaijser B. Immunology of Escherichia coli: $\mathrm{K}$ antigen and its relation to urinary-tract infection. $J$ Infect Dis $1973 ; 127$ 670-677.

5. Ørskov I, Ørskov F, Birch-Andersen A, Kanamori M, Svanborg-Edén C. O, K, H and fimbrial antigens in Escherichia coli serotypes associated with pyelonephritis and cystitis. Scand J Infect Dis 1982; Suppl 33: 18-25.

6. Bjorksten B, Kaijser B. Interaction of human serum and neutrophils with Escherichia coli strains: differences between strains isolated from urine of patients with pyelonephritis or asymptomatic bacteriuria. Infect Immun 1978; 22: 308-311.

7. Siegfried L, Puzová H, Kmetová M, Kerestešová A. Killing of alpha-haemolytic and non-haemolytic Escherichia coli strains in human serum and polymorphonuclear leucocytes. J Med Microbiol 1992; 37: 3-7.

8. Hughes C, Hacker J, Roberts A, Goebel W. Hemolysin production as a virulence marker in symptomatic and asymptomatic urinary tract infections caused by Escherichia coli. Infect Immun 1983; 39: 546-551.

9. Cavalieri SJ, Bohach GA. Snyder IS. Escherichia coli alphahaemolysin: characteristics and probable role in pathogenicity. Microbiol Rev 1984; 48: 326-343.

10. Quackenbush RL, Falkow S. Relationship between colicin V activity and virulence in Escherichia coli. Infect Immun 1979 ; 24 : 562-564.

11. Williams PH. Novel iron uptake system specified by ColV plasmids: an important component in the virulence of invasive strains of Escherichia coli. Infect Immun 1979; 26 : 925-932.

12. Jacobson SH, Hammerlind M, Lidefeldt KJ, Osterberg E, Tullus K, Brauner K. Incidence of aerobactin-positive Escherichia coli strains in patients with symptomatic urinary tract infection. Eur $J$ Clin Microbiol Infect Dis $1988 ; 7: 630-634$.

13. Johnson JR, Moseley SL, Roberts PL, Stamm WE. Aerobactin and other virulence factor genes among strains of Escherichia coli causing urosepsis: association with patient characteristics. Infect Immun 1988; 56: 405-412.

14. Caprioli A, Falbo V, Ruggeri FM et al. Cytotoxic necrotizing factor production by haemolytic strains of Escherichia coli causing extraintestinal infections. J Clin Microbiol 1987; 25: $146-149$.

15. Blanco J, Alonso MP, Gonzalez EA, Blanco M, Garabal JI. Virulence factors of bacteraemic Escherichia coli with
Because of the presence of PF in only 83 of 168 isolates tested, it may be assumed that alternative fimbrial or non-fimbrial adhesins play a role in pathogenesis in PF $^{-}$strains. $^{34-36}$ This suggestion arises from the fact that several pyelonephritogenic as well as lower UTI isolates agglutinated guinea-pig erythrocytes.

Previous reports of the association of particular serotypes with UTI was confirmed only partly in the present work. In addition to serotypes $\mathrm{O} 1, \mathrm{O} 2, \mathrm{O} 4, \mathrm{O} 6$, O7, 018 and 075 , as noted, for example, by Ørskov and Ørskov, ${ }^{2}$ and Johnson, ${ }^{37}$ isolates of serotype 0112 were common.

Plasmids were found in the majority of strains and all of the ampicillin-resistant isolates contained plasmid DNA. It is well known that antibiotic resistance is often plasmid-mediated ${ }^{38}$ but further work is needed to investigate this particular association.

particular reference to production of cytotoxic necrotising factor (CNF) by P-fimbriate strains. $J$ Med Microbiol $1990 ; 31: 175-183$.

16. Gonzales EA, Blanco J, Baloda SB, Wadström T. Relative cell surface hydrophobicity of Escherichia coli strains with various recognized fimbrial antigens and without recognized fimbriae. Zentralbl Bakteriol Mikrobiol Hyg A 1988; 269: $218-236$.

17. Domingue GJ, Roberts JA, Laucirica $R$ et al. Pathogenic significance of P-fimbriated Escherichia coli in urinary tract infections. J Urol 1985; 133: 983-987.

18. Hacker J, Schrettenbrunner A, Schroter G, Duvel G, Schmidt G, Goebel W. Characterization of Escherichia coli wildtype strains by means of agglutination with antisera raised against cloned P-, S-, and MS-fimbriae antigens, haemagglutination, serotyping and hemolysin production. Zentralbl Bacteriol Mikrobiol Hyg A 1986; 261 : 219-231.

19. Labigne-Roussel A, Falkow S. Distribution and degree of heterogeneity of the afimbrial-adhesion-encoding operon (afa) among uropathogenic Escherichia coli isolates. Infect Immun 1988; 56: 640-648.

20. Evans DG, Evans DJ, Tjoa WS, DuPont AL. Detection and characterization of colonization factor of enterotoxigenic Escherichia coli isolated from adults with diarrhoea. Infect Immun 1978; 19: 727-736

21. Smith HW. The haemolysins of Escherichia coli. J Pathol Bacteriol 1963; 85: 197-211.

22. Asnani PJ, Bhatnagar M, Bhandari S. Production and purification of Escherichia coli hemolysin. Folia Microbiol 1988; 33: $393-400$

23. Šmarda J. Incidence and manifestations of colicinogeny in strains of Escherichia coli. J Hyg Epidemiol 1960; 4: $151-165$.

24. Csáky TZ. On the estimation of bound hydroxylamine in biological materials. Acta Chem Scand 1948; 2: 450-454.

25. Birnboim HC, Doly J. A rapid alkaline extraction procedure for screening recombinant plasmid DNA. Nucleic Acids Res 1979; 7 : 1513-1523.

26. Siegfried L. Puzová H. Response of Escherichia coli strains carrying plasmid(s) and their plasmidless derivatives to bactericidal activity of human serum and polymorphonuclear leucocytes. Acta Microbiol Hung 1991; 38: 107-115.

27. Benge GR. Bactericidal activity of human serum against strains of Klebsiella from different sources. J Med Microbiol 1988; 27: $11-15$.

28. Jacobson SH, Ostenson C-G, Tullus K. Brauner A. Serum resistance in Escherichia coli strains causing acute pyelonephritis and bacteraemia. APMIS 1992; 100: 147-153.

29. Hull SI, Bieler S, Hull RA. Restriction fragment length polymorphism and multiple copies of DNA sequences homologous with probes for P-fimbriae and hemolysin genes among uropathogenic Escherichia. Can $J$ Microbiol 1988; 34: 307-311.

30. Blanco J, Alonso MP, Blanco M. Blanco JE, González EA. Garabal JI. Establishment of three categories of P- 
fimbriated Escherichia coli strains that show different toxic phenotypes and belong to particular $\mathrm{O}$ serogroups. FEMS Microbiol Lett 1992; 99: 131-136.

31. Arthur M, Johnson CE, Rubin RH et al. Molecular epidemiology of adhesin and hemolysin virulence factors among uropathogenic Escherichia coli. Infect Immun 1989; 57: 303-313.

32. Conventi L, Erico G, Mastroprimiano S, D'Elia R, Busolo F. Characterization of Escherichia coli adhesins in patients with symptomatic urinary tract infections. Genitourin Med $1989 ; 65$ : $183-186$.

33. Gander RM, Thomas VL, Forland M. Mannose-resistant hemagglutination and $\mathrm{P}$ receptor recognition of uropathogenic Escherichia coli isolated from adult patients. $J$ Infect Dis 1985 ; 151 : $508-513$.

34. MacKenzie WR, O'Hanley P. Recent advances related to virulence and host factors in urinary tract infections. Curr Opin Infect Dis 1991; 4: 31-36.

35. Nowicki B, Labigne A, Moseley S, Hull R, Moulds J. The Dr hemagglutinin, afimbrial adhesins AFA-I and AFA-III, and F 1845 fimbriae of uropathogenic and diarrheaassociated Escherichia coli belong to a family of hemagglutinins with Dr receptor recognition. Infect Immun 1990; 58: $279-281$

36. Hoschutzky H, Nimmich W, Lottspeich F, Jann K. Isolation and characterization of the non-fimbral adhesin NFA-4 from uropathogenic Escherichia coli O7: K98: H6. Microb Pathog 1989; 6: 351-359.

37. Johnson JR. Virulence factors in Escherichia coli urinary tract infection. Clin Microb Rev 1991; 4: 80-128.

38. Amyes SGB, Gemmell CG. Antibiotic resistance in bacteria. $J$ Med Microbiol 1992; 36: 4-29. 